\title{
The Impact of Customer Relationship Management on Achieving Service Quality of Banking Sector of Jordan
}

\author{
Marzouq Ayed Al-Qeed ${ }^{1}$, Basem Yousef ALsadi ${ }^{2} \&$ Zeyad F Al-Azzam ${ }^{3}$ \\ ${ }^{1}$ The World Islamic Science and Education University, Amman, Jordan \\ ${ }^{2}$ Philadelphia University, Jordan \\ ${ }^{3}$ The World Islamic Science and Education University, Jordan \\ Correspondence: Marzouq Ayed Al-Qeed, The World Islamic Science and Education University. P. O. Box 1101 \\ Postal Code 11947, Amman, Jordan. E-mail: dr_marzouq@yahoo.com
}

Received: November 29, 2016

Accepted: January 19, 2017 Online Published: February 22, 2017

doi:10.5539/ijbm.v12n3p180

URL: https://doi.org/10.5539/ijbm.v12n3p180

\begin{abstract}
Definitely, the world is becoming chaotic and affects all aspects of life. One of these is customers who become more severe in their needs, expectations, desires, and preferences. Organizations must consistently realize this issue by communicating and building effective relationships with them for better-enhancing services quality. Therefore, this study investigates the relationship between customer relationship management and service quality of Jordan banking sector. The researchers relied on descriptive and analytical approach through a survey questionnaire used to obtain data from 150 respondents who were at all levels in the 22 operating banks in Jordan, only 141 were returned but 13 of them were excluded because they were invalid for statistical analysis, only 128 questionnaires were valid and considered with a ratio of $85 \%$. The findings revealed that a moderate level of importance in customer relationships management was apparent while an increasing awareness in the service quality of banking sector of Jordan was dominant. The study also found a strong correlation between customer relationship management -except customer satisfaction and loyalty- and the service quality of banking operated in Jordan. Additionally, results showed that a significant and statistical effects at $(\mathrm{P}<0,05)$ of customer relationship management with its dimensions (customer satisfaction, customer loyalty, customer attraction, customer retention, customer value, customer culture, customer knowledge) in service quality of Jordan banking sector. Finally, study results revealed that customer knowledge, customer retention, and customer culture are the most influential dimensions in the services quality of Jordan banks sector.
\end{abstract}

Keywords: customer relationship management, customer, service quality, banking sector, Jordan

\section{Introduction}

The environment today is characterized by hyper competitive that affect every life aspect. In the era of Knowledge Economy, globalization and development of information and telecommunication technologies imposed on organizations to focus on customers who have become more aware of his needs, desires, preferences, and priorities (Ngambi \& Ndifor, 2015). Customer relationships are important for the organizations' competitive advantage sustainability, and it has increasingly studied in marketing field. Depending on new technologies, business corporations use different tools and techniques to interact with prospector customers and clients in order to attract, satisfy, and retain them. Furthermore, employees should be more knowledgeable, courteous, customer-focused, and service-oriented (Mohsan et al., 2011, Long et al., 2013).

Customer role has been increased over the prouder and/or the buyer roles and the single product is no longer the only choice of customer, this push top management to place more attention on customer as they are the cornerstone of all its marketing activities (Dominici \& Guzzo, 2010). Consequently, strengthening the relationship with customers is mandatory; therefore, Customer Relationship Management (CRM) emerged as strategic tool for coping with competitiveness. The customer-life-cycle (starting from attracting, through developing and strengthening, and finally retention customers) needs to be fully and deeply understood and go further beyond their expectations especially their needs and desires to develop products, addition to be considered as cash cow in order to spend on entering new markets (Tekin, 2013).

The pipeline of CRM is not only knowledge which is essential for gathering information about customers from 
different focal points but also the interaction between customers and organization that make top management developing marketing strategies to satisfy the wide-range of customers and bring their loyalty to both product and the organization. These by itself has no real value unless the organization has the necessary technological tools such as internet, effective call center, and customer database and information (Coltman, Devinney, \& Midgley, 2010; Simonet, Kamdem, \& Nguelefack, 2012).

Several studies have identified the necessity of sustaining a strong relationship with customers. However, banking industry of Jordan adopts customer-centric strategies in order to fully maintain and enhance this relationship with existing customers for the survival of banks (Roy and Shekhar, 2010). The evolution in telecommunications and technology services may offer many challenges to CRM. Therefore, this paper examines the effects of Customer Relationship Management (CRM) on Service Quality at banking industry of Jordan.

\subsection{Problem Background}

Today, organizations have recognized the importance of customers in their lives so that they build and develop strong interactive relationships with customers. These relationships might alter organizational short-term and long-term strategies. Organisations must know its' customers desires and expectations from one side and investigate environment especially the task and industry environment from another side to come up with not only new and innovative quality services delivered to its' customers but also attract potential customers.

Incredibly, technological developments, globalization, and competitiveness have increasingly tremendous effects on business marketing strategies in order to be more effectively to meet those challenges facing organizations, including banking sector. The more of tracing customers' behavior evolution, the narrower the knowledge gap between the organization and its' customers.

As an inevitable result, organizations realized that achieving high value-added and high-quality services does not only base on the product itself, its diversity and its properties, but also on the end-user of that product(s). It is necessary to focus on the most important element which is the customer and to understand their needs, desires, and perceptions through customer relationship management. This is basically based largely on the knowledge and how to integrate them into the philosophy of customer relationship management. Consequently, businesses face a huge challenge to attract new customers while working on retaining its current customers. Therefore, customers knowledge systems (or customer relationship management systems) is no longer effectively used and thus is highly recommended which allows the collection of data and information about current customers and potential customers, and it is easy to access and surfing by employees as well as top management to solve their problems quickly and enable organizational opportunities for growth and increasing revenue.

Generally, the major challenge faces Arab organizations nowadays is that customers are becoming more aware of their needs, desires, and preferences than ever and it is not easy to satisfy them because they are more severe in their demands with too many choices that would satisfy them. Furthermore, the customer relationship management aim is to increase organization's market share through integrating technology, procedures, and people (Shaon and Rahman, 2015). Banking sector in Jordan has realized that the backbone of its activities and businesses is customers who have the power to affect its operations; therefore, they are in face-to-face with their customers in order to retain them. Therefore, the following problem can be summarized in the follow questions:

1. Does Customer Relationship Management gain more attention in the Banking Sector of Jordan?

2. What is the relationship between CRM and Quality of Services (Products) in the Banking Sector of Jordan?

3. Does CRM affect the Quality of Services (Products) provided by Banking Sector of Jordan?

\subsection{Research Objectives}

The nature of customer behavior has been changed over the past and they become more specific in determining choices based on knowledge earned about products features and ingredients, which makes it difficult to convinced them of a single product and get their loyalty and retention. Based on the above, this study seeks to achieve the following objectives:

1. Introducing the meaning of Customer Relationship Management and Quality of Services of banking sector of Jordan.

2. Defining the CRM dimensions that affect the quality of products and service offered by banking sector of Jordan and thus its performance and profitability.

3. To examine the relationship and effects of CRM on quality of services and products offered by banking sector of Jordan. 
4. To contribute to the current Arabic literatures about the cause and effects of CRM in the quality of services provided by banking sector of Jordan.

\subsection{Research Hypothesis}

The researchers have set assumptions to this research as follow:

$\mathbf{H}_{\mathbf{0}}$ : There is no significant effect of Customer Relationship Management with its dimensions (Customer Satisfaction, Customer Loyalty, Customer Attraction, Customer Value, Customer Retention, Customer Culture, and Customer Knowledge) on Service Quality of Banking Sector of Jordan at $\mathrm{P} \leq 0.05$.

\subsection{Research Model}

To achieve the study objectives are required to build a model that depends on the structural variables in customer relationship management and the banking services quality. This is illustrated in Figure (1):

The researchers considered the following variables of their study:

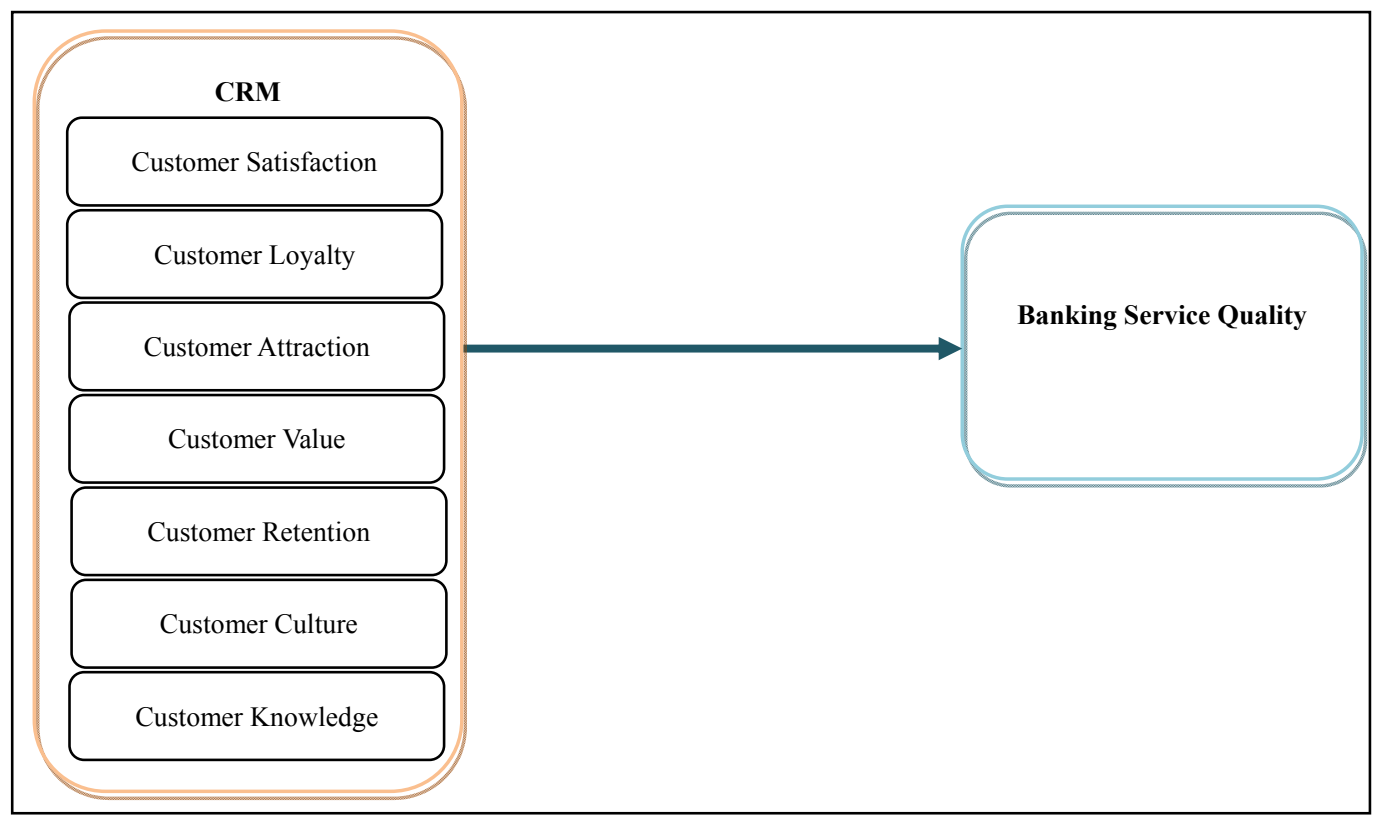

Figure 1. Research model

\subsubsection{Independent Variable}

Customer Relationship Management (CRM): is a term that refers to the practices, strategies, and techniques used by business organizations to collect, manage, develop, analyze, and preserve information about customers through a continuous survey about products and services offered to customers in order to a) improve communication processes with customers, b) keep key elements of CRM, c) identify the factors related to CRM effectiveness, and d) increase the company's sales growth. Although CRM systems are expensive, it can give employees detailed information about customers such as customer personal data, date of purchasing the product or service given, and customer's preferences and interests of the purchases (Nguye and Mutum, 2012; Reinartz, Krafft, and Hoyer, 2004, Shaon and Rahman, 2015: 25-26).

Many researchers point out that customer relationship management involves various dimensions; however, researchers will focus on the following key dimensions:

1) Customer Satisfaction: is an emotional reaction or positive feelings of expressing the difference between perceived service and customer expectations regarding specific product or service (Jeong and Lee, 2010). The customer's satisfaction is the most important criteria by which the organization can judge the quality of a product or service and is a source of loyal to the organization and thus its survival in the market. Accordingly, many organizations currently trying to build a permanent correlation with the customers to convince them that the product or service perfectly matching their expectations and needs, and it is of mutual benefit between the customer (complete satisfaction) and organization (high profits) (John and Hall, 1997 ; Kotler, 2003). 
2) Customer Loyalty: is a positive (or negative) attitude of the customer toward the business organization and its products and services. It is considered important because the loyal customer will contribute to organization in long-range. Therefore, customer loyalty is basically related to provider's ability to retain customers and persuade them to recommend its products and services to potential customers (Zeithaml, Berry, and Parasuraman, 1996; Zeithaml, 2000). Often, there are three levels of loyalty according to the model of customer loyalty; a) strong loyalty where the customer is willing to buy all the times, b) moderate loyalty where the customer has a loyalty to more than two trademarks, and c) weak loyalty where the customer's preferences are varied from brand to another (Casalo et al., 2010; Lin and Wang, 2006), The purpose of customer loyalty is to retain the customer as long as possible if not always-preserved.

3) Customer Value: is the process of exchange or swap conducted by the customer between the benefits obtained from the product or service and the cost of obtaining in terms of product benefits, services attribution, the parties involved the purchase, the time and effort to obtained the product, and the risk perceived. Therefore, understanding customer's needs, desires, and preferences is thus amongst organizations priorities to find out a unique product-service value of the customer and also achieve better value for the organization that usually appears in the form of sales volume, revenue, market share, and exploit the opportunities (Cheverton, 2010; Kotter, 1995). Eventually, to create customer value more apparently, three main aspects should be dealt carefully; targeting customers, create consensus, and organize the organization's capabilities.

4) Customer Attraction: refers to the organization's ability to highly possess new prospectus customers, and that is to focus on quality standards, which positively reflected on the change in customer behavior and met the needs and desires of the customer. Satisfying customer's needs and desires and considering their suggestions and opinions gives a strong push to improve the product and/or service that drive a customer loyalty to the brand and organization, in other words it's about exceeding customer's expectations so that they become loyal advocates for your brand. (Pearce and Robinson, 2005; Kipkosgei and Njeru, 2014).

5) Customer Retention: it is the solid activities a firm undertakes to prevent customers from defecting to alternative firms. Successful customer retention starts with the first contact and continues throughout the entire lifetime of the relationship. It refers to keep customers loyal to the brand and the organization on a long range.

6) Customer Culture: means the values, knowledge, experiences, and behaviors customers hold about the products and services provided in terms of quality either low or high. Thus many studies have shown that a strong customer culture is considered an effective engine for organizations performance as well as strengthening market strategies.

7) Customer Knowledge (CK): refers to the dynamic combination of experience, value and insight information which is analyzed, interpreted, and converted to know how to exchange of knowledge between business organizations and their customers (Zanjani, Rouzbehani, and Dabbagh, 2008; Ogunde et al, 2010 ).

\subsubsection{Dependent Variables}

Service Quality (SQ): means a set of behaviors, characteristics, and techniques used to meet and satisfy customers' needs, desires, priorities, and preferences. (Parasuraman, Berry, and Zeithaml, ,1988) developed a model called 'SERVQUAL' rely on customers' expectations and perceptions of the actual service performance provided. The main objective of 'SERVQUAL' model is to identify the gaps that affect the customers' perception of service quality. Hence, this model seeks customers' satisfaction and loyalty which is considered as the cornerstone of evaluating service quality in term of its actual performance to meet their needs (Lee, 2011; Mualla, 2011; Wahab, Al-Momani, and Mohd-Noor, 2010). But the quality of banking services dimensions can be relied upon to measure the quality of service received by the customer and the extent of the real value learned from this product or service include: Tangibility, Reliability, Responsiveness, Assurance, Empathy (Adeoye and Lawanson, 2012)

\section{Literature Review}

By investigating Customer Relationship Management (CRM) system at Student Admission section in Malaysian higher education institution (Virgiyanti, Abu Bakar, and Tufail, 2011) conducted their study aimed to study the customers' satisfaction to the service given by the university. To achieve the objectives, survey was conducted to analyze the implementation of CRM and quality of the service provided. A dissatisfaction of service provided by the University staff and lack of relationship management with students (as customers) was the main result of the study.

In their study (Awwad and Al-adaileh, 2012) conducted a study aimed at investigating the factors determining CRM practices within the context of Jordanian Commercial Banks (JCBs).a 400 questionnaire were distributed 
while 309 questionnaires were analyzed by using SPSS. Their study results apparently revealed that there were five factors generated from this study including interactive management, customers prospecting, customer surveying, responsiveness to customers, and partnerships respectively that contributed to CRM implementation in JCBs.

Kesuma et al. (2013) investigated the effect of service quality on patients' loyalty and customer relationship management at private hospital industry. The results showed that service quality has positively and significantly influenced customer loyalty. In addition, implementation of CRM mediated the relationship and effect of service quality on customer loyalty.

On the other hand, Surarchith and Singh (2013) explore the key dimensions of service quality for mobile services in the telecom sector and to ascertain which aspect of service quality have significant impact on customer satisfaction. Results approved that obtaining customer satisfaction depends to a large extent on ensuring that the firm maintains high service quality standards. Also, quality mechanisms have significant effect on the level of customer satisfaction. Among the service quality variables that significantly affected customer satisfaction include competence, courtesy, tangibility, reliability, responsiveness and communication.

ALghaswyneh (2014) explores the kind of relationship marketing strategies that Umniah Mobile Company of Jordan is pursuing in today's rapidly changing and highly competitive environment, and to analyse it's outcome on the service quality and satisfaction of customers. Also, it focuses on studying the relationship between the consumers and staff working in the Umniah mobile company of Jordan. Results of the study indicate that there exists a relationship between them, but it needs further growth.

Melisidou, Venetsanopoulou, and Sergopoulos (2015) conducted a study entitled "Service Quality and CRM Implementations: Keys for Excellence in Hospitality Industry", the aim of this study was to investigate the effectiveness of practicing Customer Relationship Management Systems and its positive impacts in Service Quality issues, also to sustain that CRM application can be consider as a tool to improve customer satisfaction, retention and service quality, and finally to assess that the implementation of service quality, perceived as the major potential for the competitiveness and substantial benefits to hotel enterprises, in terms of long-term profitability. Results indicated that perceived quality and satisfaction have been shown to be good predictors of visitors' future behavioral intentions.

\section{Research Methodology}

\subsection{Sampling}

The study was focused on Banks that operated and functioning in Jordan. These banks represents local (16 banks) and foreign (9 banks) (Central Bank of Jordan, 2016). A random sample was driven from those banks included 150 employees.

\subsection{Research Instrument}

To achieve the objectives of the study and answer its questions, the researchers developed a Questionnaire based on Likert-Scale uses; 1 as Strongly Agree to 5 strongly Disagree, which included the following variables:

- Demographic variables such as sex, age, experience, educational qualification, job level, and the number of the bank's branches.

- Customer Relationship Management variables included key dimensions such as Customer Satisfaction, Customer Loyalty, Customer Attraction, Customer Value, Customer Retention, Customer Culture, and Customer knowledge.

\section{○ Quality Services Variable.}

150 questionnaires were distributed, only 141 questionnaires were returned and thus 128 were valid for statistical analysis with ration of $85.3 \%$.

\subsection{Data Analysis}

Frequencies and Standard Deviation are used as well as Spearman correlation coefficient analysis to figure out the relationship between study variables, in addition to Multiple-Regression analysis to examine the effect of the independent variables (CRM) on the dependent variable (SQ) in banking sector of Jordan.

\subsection{Validity and Reliability}

This study was used a questionnaires that had content validity and reliability with Choronbach's Alpha. Results appear in Table 1. 
Table 1. Study instrument reliability

\begin{tabular}{ll}
\hline Variables & Choronbach Alpha \\
\hline $\begin{array}{l}\text { Customer Relationship Management (CRM) } \\
\text { Customer Satisfaction }\end{array}$ & $\mathbf{0 . 9 3 2}$ \\
Customer Loyalty & $\mathbf{0 . 9 2 1}$ \\
Customer Attraction & \\
Customer Value & 0.916 \\
Customer Retention & \\
Customer Culture & 0.917 \\
Customer Knowledge & 0.893 \\
Services Quality & 0.91 \\
\hline
\end{tabular}

$* *$ Significant at $\leq 0.05$.

\section{Results}

\subsection{Demographic Variables}

Table 2 shows the results of study sample characteristics, where the results indicated that males were dominant in the Jordanian banking sector (57\%) in comparing with females (43\%) of the study population. Also notably those young and ambitious employees in their age category of (31-39) represent $40.6 \%$ followed by age category (40-49) which covers $27.3 \%$. Matching with age categories, the level of education is high as $71.9 \%$ were holding BA degree, more impressively $15.6 \%$ holding Master degree, and progressively $3.9 \%$ holding $\mathrm{PhD}$ degree. Obviously, the results in table 2 shows that employees at Jordan banking sector were more experienced where those who possesses moderate experience 6-11 years represent $47.7 \%$ while those who possesses $12-17$ years is higher in their experience represent $32.8 \%$, and those who had high experiences than others 18 years and above covers $10.2 \%$, and therefore we can say that Jordan banking sector staffs has high cumulative value $\&$ expertise and they can significantly contribute to the achievement of strategic objectives of the banks. Most of employees were situated in operational level with a ration of $56.3 \%$ and followed by head section $31.3 \%$. Eventually, the banks' sizes were ranging from moderate to large size corporations with more than 6 branches all over Jordan.

Table 2. Descriptive variables

\begin{tabular}{llll}
\hline Variable & & Frequency & Percent \\
\hline Gender & Male & 73 & 57 \\
Age & Female & 55 & 43 \\
& less than 30 & 32 & 25 \\
& $31-39$ & 52 & 40.6 \\
& $40-49$ & 35 & 7 \\
Education Level & More than 50 & 9 & 8.6 \\
& Diploma and less & Bachelor & 71.9 \\
Experience & Master & 11 & 15.6 \\
& PhD & 92 & 3.9 \\
& Less than 5 Years & 20 & 9.4 \\
Post & $6-11$ & 5 & 47.7 \\
& $12-17$ & 12 & 32.8 \\
& More than 18 & 61 & 10.2 \\
& Branch Manager & 42 & 3.9 \\
& Department Manager & 13 & 8.6 \\
& Head Section & 5 & 31.3 \\
& Staff & 11 & 56.3 \\
& less than 5 Branches & 40 & 13.3 \\
& $6-10$ & 72 & 28.1 \\
& $11-15$ & 17 & 44.5 \\
& More than 12 & 36 & 14.1 \\
\hline
\end{tabular}




\subsection{Basic Study Variables}

Table 3 scrutinised the level of importance of the dimensions of Customer Relationship Management and the dimensions of the Services Quality of banking sector of Jordan. It can be inferred that the respondents attitudes toward level of importance of customer relationship management in banking sector of Jordan was obviously moderate (mean=3.290) which came contrary to the expectations of high levels of CRM importance. This implies that the degree of employees' consciousness wasn't evolved simultaneously. Neither do any CRM dimension generating high levels of importance. On the contrary, respondents attitudes toward levels of importance of banking services quality were high (mean=3.653). Consequently, the high levels of importance of banks services quality reflect the point of view for banks' management with small attention to customer's needs and expectations. In contradict with moderate levels of importance of CRM, researchers believe that the operated banks of Jordan have not focused on customers' perceptions, desires, and preferences in terms of quality products and services offered and this is the reason why customers are waived to another banks.

Table 3. Study variables

\begin{tabular}{llll}
\hline Variable & Mean & Standard Deviation & Level of Importance \\
\hline Customer Relationship Management & 3.281 & 0.9085 & Moderate \\
Customer Satisfaction & 3.220 & 0.9094 & Moderate \\
Customer Loyalty & 3.313 & 0.8182 & Moderate \\
Customer Attraction & 3.338 & 0.8876 & Moderate \\
Customer Value & 3.308 & 0.8425 & Moderate \\
Customer Retention & 3.306 & 0.8755 & Moderate \\
Customer Culture & 3.255 & 0.9031 & Moderate \\
Customer Knowledge & 3.290 & 0.7550 & Moderate \\
\hline
\end{tabular}

\subsection{Hypothesis Testing}

\subsubsection{Correlation Coefficients}

First hypothesis was tested by conducted Pearson correlation to test whether relationships exist between Customer Relationship Management and Services Quality as shown in Table 4. According to correlation analysis Customer Relationship Management was strongly positive in relationships with Services Quality $(0.985, \mathrm{P} \leq 0.05)$. Moreover, despite that results show a strong and positive relation between each CRM dimensions and Services Quality; Customer Attraction (0.784), Customer Value (0.902), Customer Retention (0.924), Customer Culture (0.903), and Customer Knowledge (0.942) and all were statistically significant at $\mathrm{P} \leq 0.05$, same results show no significant and positive relationship between Customer Satisfaction (-0.067), Customer Loyalty (-0.017) and Service Quality. These results were surprising the authors where customers' satisfaction is associated with service quality provided by different industries.

Table 4. Correlations

\begin{tabular}{ll}
\hline Independent Variable & $\begin{array}{l}\text { Dependent Variable } \\
\text { Services Quality }\end{array}$ \\
\hline Customer Relationship Management & $0.985^{* *}$ \\
Customer Satisfaction & -0.067 \\
Customer Loyalty & -0.017 \\
Customer Attraction & $0.784^{* *}$ \\
Customer Value & $0.902^{* *}$ \\
Customer Retention & $0.924^{* *}$ \\
Customer Culture & $0.903^{* *}$ \\
Customer Knowledge & $0.942^{* *}$ \\
\hline
\end{tabular}

** Significant at $\leq 0.05$.

\subsection{Regression Analysis}

Table 5 summarizes the regression analysis results for CRM on Services Quality. It is found that CRM dimensions overall have positive relationship with Services Quality in banking sector of Jordan ( $\mathrm{R}=0.977)$. 
However, base on the adjusted $\mathrm{R}$ square value of 0.954 , these dimensions explain $95.4 \%$ of variance of dependent variable which is Services Quality. It is obvious that independent variable with higher level of $\beta$ has higher impact on dependent variable; therefore, study results revealed that the dimension of Customer Knowledge has significant impact on Services Quality with t-statistic 6.759 and significance level is 0.000 , which is less than P-value 0.05 and the Beta value $(\beta=.623$, sig $<.05)$ is the most influential dimension on SQ followed by Customer Retention with Beta value $(\beta=.157$, sig<.05), t-statistics 1.522 and significant at 0.000 . Moreover, Customer Culture has shown the third influential dimension with t-statistics 1.455 and significant at 0.001 , also the Beta value $(\beta=.147$, sig<.05) reflects the percent of change in dependent variable if Customer Culture changed by $1 \%$, then it followed by Customer Value $(\beta=.121$, sig $<.05)$, Customer Attraction $(\beta=.076$, sig<.05), Customer Loyalty $(\beta=.049$, sig<.05), and finally Customer Satisfaction $(\beta=.046$, sig $<.05)$ and significant at $0.002,0.004,0.000$, and 0.001 respectively. Thus supporting $\mathrm{H}_{0}$, that $\mathrm{CRM}$ and its dimensions have positive and significant impact on Services Quality provided by banking sector of Jordan.

Table 5. Multiple-Regression for CRM on Services Quality

\begin{tabular}{lcccc}
\hline Model & $\mathrm{R}$ & $\mathrm{R}$ Square & Adjusted R Square & Std. Error of the Estimate \\
\hline 1 & $.977^{\mathrm{a}}$ & .954 & .952 & .06287 \\
\hline $\begin{array}{l}\text { a. Predictors: (Constant), CRM, Satisfaction, Loyalty, Customer attraction, Customer value, Customer culture, Customer retention, Customer } \\
\text { knowledge }\end{array}$
\end{tabular}

Table 6. ANOVA ${ }^{\mathrm{b}}$

\begin{tabular}{lllllll}
\hline Model & & Sum of Squares & df & Mean Square & F & Sig. \\
\hline 1 & Regression & 9.885 & 6 & 1.648 & 416.863 & $.000^{\mathrm{a}}$ \\
& Residual & .478 & 121 & .004 & & \\
& Total & 10.364 & 127 & & & \\
\hline
\end{tabular}

a. Predictors: (Constant), CRM, Customer satisfaction, Customer Loyalty, Customer Contraction, Customer Value, Customer Culture, Customer Retention, Customer Knowledge

b. Dependent Variable: SERVICEQ UALITY.

Table 7. Coefficients

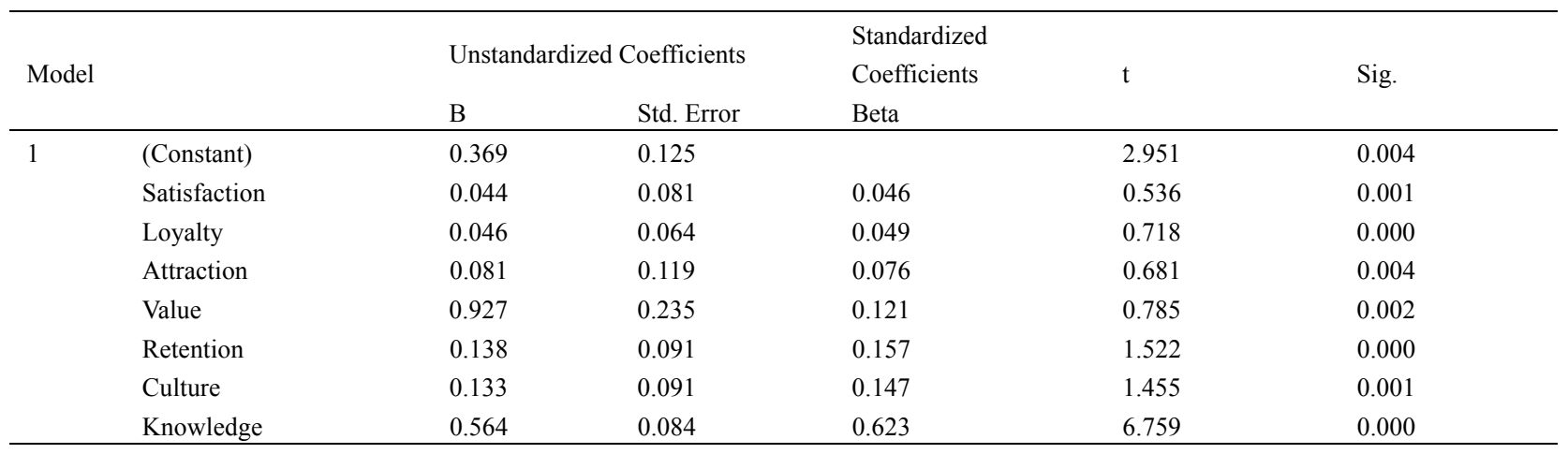

a. Dependent variable: service quality.

\section{Discussions}

Of course, results indicated that the level of importance given to customer relationship management and its dimensions were moderate while the level of importance toward the services quality banking services was high. Moreover, results above revealed positive correlation between customer relationship management relationship (customer attraction, customer value, customer retention, customer culture, and customer knowledge) and services quality of banking services but results showed that lack of or negative relationships between customer satisfaction and customer loyalty of the customer relationship management and services quality of banking services. These results have come contrary to the expectations, where the researchers have higher expectations of positive and significant relationship between customer satisfaction and loyalty with services quality. The rule is 
said that as services quality is perceived important to the both organization and customers, it would increasingly lead to higher satisfactions and loyal to the product and services brands (Dhman, 2011; Shavazi, 2013). This could be investigated further in depth. Nevertheless, too many studies conducted on the relationship and effects of CRM on Services Quality and organizational performance as well as customers' satisfaction, loyalty, and retention, these studies concluded to the higher impact of CRM on customers perception, satisfaction, loyalty ... etc.

On the other hand, results of this study concluded that there was statistically significant impact of Customer Relationship Management dimensions (customer satisfaction, customer loyalty, customer attraction, customer retention, customer value, customer culture, and customer knowledge) on Banking Services Quality in Jordan at $\mathrm{P} \leq 0.05$.

Finally, study results showed that Customer Knowledge, Customer Retention, and Customer Culture were the most influential dimensions in the Services Quality of banking services followed by Customer Value, Customer Attraction, Customer Loyalty, and Customer Satisfaction. Naturally, Customer Knowledge is becoming nowadays critical where the new era of technology development make customers more aware than ever so that it is difficult to satisfy them in terms of products and services provided. Organizations should do more emphasizes on customers relations to convince them with products and services not only meet their needs but go further beyond their expectations (Amoako et al., 2012; Krishnamoorthy \& Srinivasan, 2013).

\section{Future Implications and Recommendations}

In light of study findings, this paper provides important implications for effective management of Customer Relationship Management including all different sub-variables that would have strong impact on Services Quality at all corporations. Having this notion means possessing competitive advantage over other competitors in a hyper-competitive market. To retain customers requires organizations creating committed customers so that they contributed to its products and services quality, in addition, customer loyalty considered the pipeline for customer satisfaction and thus commitment to organizations products and services which in turn increase customer retention (Verhoef, 2003; Patrick, 2012). In other words, developing and increasing close ties with customers is the most influential strategy to enhance customer loyalty (Nguyen \& Mutum, 2012).

In general, most business organizations use multiple strategies to increase customers' satisfaction, loyalty, and commitment, and to affect customers' retention and customers' share. The main principal of CRM is to place more emphasis on the more loyal customers and increase their share as their tendency is to be reduced in future.

Therefore, further researches should intensively focus on conducting more studies on CRM including all variables related to customers and tie them with customer relationship perception (CRP) and relationship marketing instrument (RMI) in the service and non-service sectors. Also, CRM could be further investigated in term of its effect on organizational financial performance as it might be explored in term of organizational citizenship behavior.

\section{References}

Adeoye, B., \& Lawanson, O. (2012). Customers Satisfaction and its Implications for Bank Performance in Nigeria. British Journal of Arts and Social Sciences, 5(1), 13-29.

ALghaswyneh, O. F. (2014). The Impact of Implementing Customer Relationship Management in UMNIAH Mobile Company Jordan. European Journal of Business and Social Sciences, 2(10), 169-181.

Amoako, G., Arthur, E., Bandoh, C., \& Katah, R, (2012). The impact of effective customer relationship management (CRM) on repurchase: A case study of (GOLDEN TULIP) hotel (ACCRA-GHANA). African Journal of Marketing Management, 4(1), 17-29.

Awwad, M. S., \& Al-adaileh, R. M. (2012). Factors Determining Customer Relationship Management Practices: The Context of Jordanian Commercial Banks. Jordan Journal of Business Administration, 8(1), 208-220.

Casalo, L., Flavian, V., \& Cand, G. M. (2010). Relationship Quality, Community Promotion and Brand Loyalty in Virtnal Communities: Evidence from Free Software Communities Interactional. Journal of Information Management, 1-11.

Cheverton, P. (2010). Building the Value Machine. London and Philadelphia, Kogan Page.

Coltman T., Devinney T., \& Midgley D. (2011). Customer relationship management and firm performance. Journal of Information Technology, 26(3), 205-219. https://doi.org/10.1057/jit.2010.39 
Dhman Z. A. (2011). The Effect of Customer Relationship Management (CRM) Concept Adoption on Customer Satisfaction-Customers Perspective: The Case of Coastal Municipalities Water Utility CMWU-Rafah Branch. (Master Thesis- Unpublished), Islamic University-Gaza Strip.

Dominici, G., \& Guzzo R. (2010). Customer Satisfaction in the hotel Industry-A case study of Sicily. International Journal of Marketing Studies, 2(2), 3-12. https://doi.org/10.5539/ijms.v2n2p3

Jeong, Y., \& Lee, Y. (2010). A Study on the Customer Satisfaction and Customer Loyalty of Furniture Purchaser in On-Lline Shop. Asian Journal on Quality, 11(2), 146-156. https://doi.org/10.1108/15982681011075952

Kesuma, I. A., Hadiwidjoj D., Wiagustini, N. L., \& Rohman, F. (2013). Service Quality Influence on Patient Loyalty: Customer Relationship Management as Mediation Variable (Study on Private Hospital Industry in Denpasar). International Journal of Business and Commerce, 2(12), 1-14.

Kipkosgei, B. C., \& Njeru, A. (2014). Effects of New Product Development on Customer Attraction by Saccos in Baringo County Kenya. International Journal of Business and Commerce, 3(8), 112-119.

Kotter, J. P. (1995). Leading Change: Why Transformation Efforts Fail. Harvard Business Review, 73(2), 59-67.

Krishnamoorthy, V., \& Srinivasan, R. (2013). The Impact of Customer Relationship Management on Loyalty in Indian Banking Sector-An Empirical Study. International Monthly Refereed Journal of Research In Management \& Technology, 11(June), 150-161.

Lee, C. J. (2011). Understanding Bank Service Quality in Customers' Terms: An Exploratory Analysis of Top-Of-Mind Definition. International Journal of Business and Social Science, 2(21), 1-7.

Melisidou, S., Venetsanopoulou, M., \& Sergopoulos, K. (2015). Service quality and crm implementations: keys for excellence in hospitality industry. International Conference 'Science in Technology' SCinTE 2015, http://www.scinte.gr/abstracts/10\%20Management\%20Science,\%20Finance,\%20Economics\%20\&\%20Tou rism/SCinTE-240-A10-161.pdf

Mualla, N. D. (2011). Assessing the Impact of Sales Culture on the Quality of Bank Services in Jordan. Journal of Business Administration, 7(1), 148-178.

Ngambi, M., \& Ndifor, P. (2015). Customer Relationship Management and Firm Performance: Revisiting the Case of CAMCCUL Microfinance Institutions. International Journal of Information Technology and Business Management, 38(1), 12-21.

Nguyen, B., \& Mutum, D. (2012). A review of customer relationship management: successes, advances, pitfalls and futures. Business Process Management Journal, 18(3), 400-419. https://doi.org/10.1108/14637151211232614

Ogunde, A. O., Folorunso, O., Adewale, O. S., Ogunleye, G. O., \& Ajayia, A. O. (2010). Towards An Agent-Based Customer Knowledge Management Systems (ABCKMS) in E-Commerce Organizations. International Journal on Computer Science and Engineering, 2(6), 2181-2186.

Parasuraman, A., Zeithaml, V., \& Berry, I. (1988). SERVQUAL: A Multiple-Item Scale for Measuring Consumer Perception of Service Quality. Journal of Retailing, 64(1), 12-40.

Patrick, O. O. (2012). Moderating Customer Relationship Management (CRM) to Enhance Firm Performance through Continuous Product Development. Australian Journal of Business and Management Research, 2(1), $1-8$.

Pearce, J., \& Robinson, R. (2005). Strategic management formulation implementation and Control (10th ed), McGraw-Hill Publishers Ltd.

Reinartz, W., Krafft, M., \& Hoyer, W. D. (2004). The Customer Relationship Management Process: Its Measurement and Impact on Performance. Journal of Marketing Research, 41(3), 293-305. https://doi.org/10.1509/jmkr.41.3.293.35991

Shaon, K., \& Rahman, H. (2015). A Theoretical Review of CRM Effects on Customer Satisfaction and Loyalty. Prague Economic Papers, 4(1), 23-36.

Shavazi, E. T., Moshabaki, A., Hoseini, S. H., Naiej, A. K. (2013). Customer Relationship Management and Organizational Performance: A Conceptual Framework Based On the Balanced Scorecard (Study of Iranian Banks). Journal of Business and Management (IOSR-JBM), 10(6), 18-26. https://doi.org/10.9790/487X-1061826 
Simonet, M., Kamdem, D., \& Nguefack, C. (2012). Impact of the Customer relationship management on the performance of the Institutions of Microfinance in Cameroon; The case of the CAMCCUL network. International Journal of Management \& Information technology, 1(3), 37-53.

Surarchith, N. K., \& Singh, U. S. (2013). A Study on the Service Quality and it's Relation to CRM in Telecom Industry. Industrial Engineering Letters, 3(5), 50-58.

Tekin, M. (2013).“Critical Success Factors for a Customer Relationship Management Strategy. Mediterranean Journal of Social Sciences, 4(10), 753. https://doi.org/10.5901/mjss.2013.v4n10p753

Verhoef, P. C. (2003). Understanding the Effect of Customer Relationship Management Efforts on Customer Retention and Customer Share Development. Journal of Marketing, 67, 30-45. https://doi.org/10.1509/jmkg.67.4.30.18685

Virgiyanti, W., Abu Bakar, AH., \& Tufail, M. A. (2011). Investigating Customer Relationship Management and service quality in Malaysian higher education. Asian Journal of Management Research, 1(2), 578-593.

Wahab, S., Al-Momani, K., \& Mohd-Noor, N. (2010). The Relationship between E- Service Quality and Ease of Use on Customer Relationship Management (CRM) Performance: An Empirical Investigation In Jordan Mobile Phone Services. Journal of Internet Banking and Commerce, 15(1), 1-15. https://doi.org/10.1109/ic4e.2010.113

Zanjani, S. M., Rouzbehani, R., \& Dabbagh, H. (2008). Proposing a Conceptual Model of Customer Knowledge Management: A Study of CKM Tools in British Dotcoms. International Journal of Social, Behavioral, Educational, Economic and Management Engineering, 2(2), 51-55.

Zeithaml, V. A. (2000). Service Quality, profitability and the Economic worth of Customers: What we Know and What we Need to Learn. Journal of the Academy of Marketing Science, 28(1), 67-85. https://doi.org/10.1177/0092070300281007

Zeithaml, V. A., Berry, L. L., \& Parasuraman, A. (1996). The Behavioral Consequences of Service Quality. The Journal of Marketing, 60(2), 31-46. https://doi.org/10.2307/1251929

\section{Copyrights}

Copyright for this article is retained by the author(s), with first publication rights granted to the journal.

This is an open-access article distributed under the terms and conditions of the Creative Commons Attribution license (http://creativecommons.org/licenses/by/4.0/). 